\title{
Effect of Solvent Types on Characteristics of Elephant Ginger (Zingiber Officinale, Rosc) Oleoresin with Leaching Process
}

\section{Pengaruh Jenis Pelarut Terhadap Karakteristik Oleoresin Jahe Gajah (Zingiber Officinale, Rosc) dengan Proses Leaching}

\author{
Rizka Mila Nurdiana ${ }^{\text {a,1,* }}$, Nur Laili Indah Pamungkas a,2, Bambang Wahyudi a,3 \\ a Program Studi Teknik Kimia, Fakultas Teknik, Universitas Pembangunan Nasional “Veteran” Jawa Timur, Jl.Raya Rungkut Madya 1 Surabaya, 60249, \\ Indonesia \\ ${ }^{1}$ rizkamilanurd@gmail.com *; ${ }^{2}$ lailiindah84@ gmail.com; ${ }^{3}$ bwahyudi11@yahoo.com \\ * corresponding author
}

ARTICLE INFO

Article history

Received March 30, 2021

Revised August 09, 2021

Accepted September 03, 2021

Keywords

Essential oil

Ginger

Oleoresin

Oleoresin characteristic

Solid-liquid extraction

\begin{abstract}
Ginger is one of the important agricultural commodities for the Indonesian economy. Ginger contains (Zingiber officinale, Rosc) oleoresin and essential oils. This research aims to find out whether the type of solvent and mass of ginger affects the result and characteristic of oleoresin produced. The method has been used in this research is solid-liquid extraction (leaching). The variables used are solvent types (ethanol, $n$-hexane, ethanol:hexane) with a volume $1000 \mathrm{ml}$ and mass of ginger $(100,150,200,250,300$ grams). The results showed that Ethanol solvent produced the highest yield of 11,663\% at a ginger mass of 100 grams, while n-hexane solvent produced the smallest oleoresin yield of 1,5474\% at a ginger mass of 300 grams. Analysis of oleoresin quality characteristics consists of density value, solubility in alcohol, contained components, refractive index and optical rotation is carried out on extract with the highest yield. The extract was analyzed by GC$M S$ to determine its content. The result of analysis showed the presence of gingerol $(58,97 \%)$ and shogaol $(4,65 \%)$ on extract. In addition to the optical rotation value, oleoresin has quality characteristics that are in accordance with the established quality standards.
\end{abstract}

This is an open access article under the CC-BY-SA license.

\section{Pendahuluan}

Indonesia sebagai negara agraris mempunyai banyak tanaman yang bisa dioptimalkan sebagai obat-obatan, terdapat kecenderungan masyarakat untuk beralih ke bahan alami yang menjadikan peluang bahan alami untuk menjadi komoditas kebutuhan dibidang farmasi atau dalam bidang yang lain. Indonesia menjadi salah satu penghasil jahe (Zingiber officinale) tertinggi di bumi dengan luas lahan panen $105.560 .126 \mathrm{~m}^{2}$ dan total produksi jahe $174.380 .120 \mathrm{~kg}$ [1], sehingga produk turunan dari rimpang jahe berpeluang besar untuk dikembangkan [2].

Jahe mengandung oleoresin yang banyak dimanfaatkan di industri farmasi dan industri makanan. Oleoresin merupakan produk yang pembuatannya berasal dari rempah, umumnya berupa minyak kental dalam suhu tinggi serta berbentuk pasta dalam suhu ruang. Oleoresin jahe memiliki kandungan minyak atsiri berkisar 15-35\% biasanya berupa cairan berwarna coklat tua, agak kental yang memiliki aroma rasa jahe. Komponen penyusun oleoresin berisi campuran-campuran fenolik aktif yang terdiri dari gingerol, shogaol, dan resin. Komponen-komponen tersebut mempunyai sifat anti-inflamasi, anti-angiogenesis, antioksidan, anti-kanker, dan anti artheosklerotik. Dalam proses 
pengolahan pangan, oleoresin jahe diperoleh dari proses pengambilan intisari jahe kering, tepung jahe serta rimpang jahe yang segar [3].

Proses pengambilan minyak atsiri dapat dilakukan menggunakan metode ekstraksi ataupun metode penyulingan [4]. Ekstraksi merupakan suatu proses pemisahan zat dari campurannya, terbagi menjadi zat telarut dan zat pelarut. Proses ekstraksi menggunakan dua pelarut yang tidak bercampur untuk mengambil zat terlarut dari satu pelarut ke pelarut lain. Terdapat beberapa macam metode ekstraksi, salah satunya adalah ekstraksi padat cair (leaching) yang merupakan metode penguraian suatu zat yang terlarut dari padatan dengan mengontakkannya dengan pelarut [5]. Ekstrak yang dihasilkan dapat dipisahkan dari pelarutnya menggunakan metode distilasi. Distilasi merupakan suatu proses pemisahan kimia untuk memisahkan komponen-komponen berdasarkan pada perbedaan titik didih, sehingga didapatkan senyawa yang murni [6].

Penggunaan jenis pelarut yang berbeda dapat mempengaruhi karakteristik oleoresin jahe yang didapat, baik itu dalam segi kuantitas maupun kualitas pada oleoresin jahe. Air merupakan pelarut yang biasanya paling sering dimanfaatkan dalam aktivitas kesehariannya. Namun minyak atsiri tidak larut dengan air namun akan larut dengan alkohol. Oleh karena itu, pemilihan pelarut yang utama adalah pada daya larut yang dimiliki dan kandungan pelarut tersebut [7]. Selain itu, polaritas pelarut juga memiliki pengaruh terhadap daya larut suatu zat. Untuk mengetahui kelarutan pelarut dapat dilihat dari besarnya konstanta dielektrik dan nilai polaritasnya, hal tersebut dikarenakan Polaritas berbanding lurus dengan konstanta dielektrik [8].

Pemeriksaan kualitas oleoresin dapat dilihat dari karakteristik fisiko kimia yang terdiri dari indeks bias, berat jenis, kelarutan dalam alkohol dan putaran optik [9]. Standar mutu minyak atsiri dari jahe mengacu pada SNI-06-1312-1998 disajikan pada Tabel 1.

Tabel 1. Spesifikasi Syarat Mutu Minyak Jahe

\begin{tabular}{ccc}
\hline Jenis Uji & Satuan & Persyaratan \\
\hline Warna & & Kuning muda - oranye \\
Bobot jenis $25^{\circ} \mathrm{C} / 25^{\circ} \mathrm{C}$ & $\mathrm{gr} / \mathrm{ml}$ & $0,8720-0,8890$ \\
Indeks bias $25^{\circ} \mathrm{C}$ & - & $1,4853-1,4920$ \\
Putaran optic & - & $\left(-32^{\circ}\right)-\left(-14^{\circ}\right)$ \\
Kadar minyak atsiri, min & $\%$ & $1,5 \%$ \\
Bilangan asam & $\mathrm{mg} \mathrm{KOH} / \mathrm{g}$ & Maks. 2 \\
Bilangan ester & $\mathrm{mg} \mathrm{KOH} / \mathrm{g}$ & Maks. 15 \\
Minyak lemak & - & Negatif \\
\hline
\end{tabular}

Selain karakteristik fisiko kimia, kandungan senyawa fenol dalam oleoresin juga menentukan mutu oleoresin [11]. Komponen kimia minyak atsiri diidentifikasi menggunakan alat bantu kromatografi gas yang digabungkan dengan alat spektofometer massa (GC-MS). Secara kuantitatif, komponen kimia minyak atsiri dapat dianalisis menggunakan alat GC-MS yang memuat sejumlah besar data dari spektrum massa senyawa asli yang sudah ditentukan [12].

Pada penelitian ini bertujuan untuk menghasilkan oleoresin jahe gajah menggunakan dua jenis pelarut organik yang berbeda. Penggunaan pelarut yang berbeda adalah untuk mengetahui pengaruh dari jenis pelarut yang digunakan terhadap karakteristik minyak jahe yang dihasilkan. Selain itu, untuk mengetahui pengaruh berat bahan yang digunakan terhadap rendemen oleoresin jahe yang dihasilkan.

\section{Metodologi Penelitian}

\subsection{Bahan Penelitian}

Jahe gajah diperoleh dari kebun budidaya jahe Sidoarjo, pelarut etanol 96\% dan n-heksana yang diperoleh dari UD Sumber Ilmiah Persada Surabaya.

\subsection{Alat}

Pada penelitian ini adalah digunakan serangkaian alat ekstraksi padat-cair sebagai alat ekstraksi dan serangkaian alat distilasi uap-air untuk proses pemurnian tersaji ada Gambar 1. 

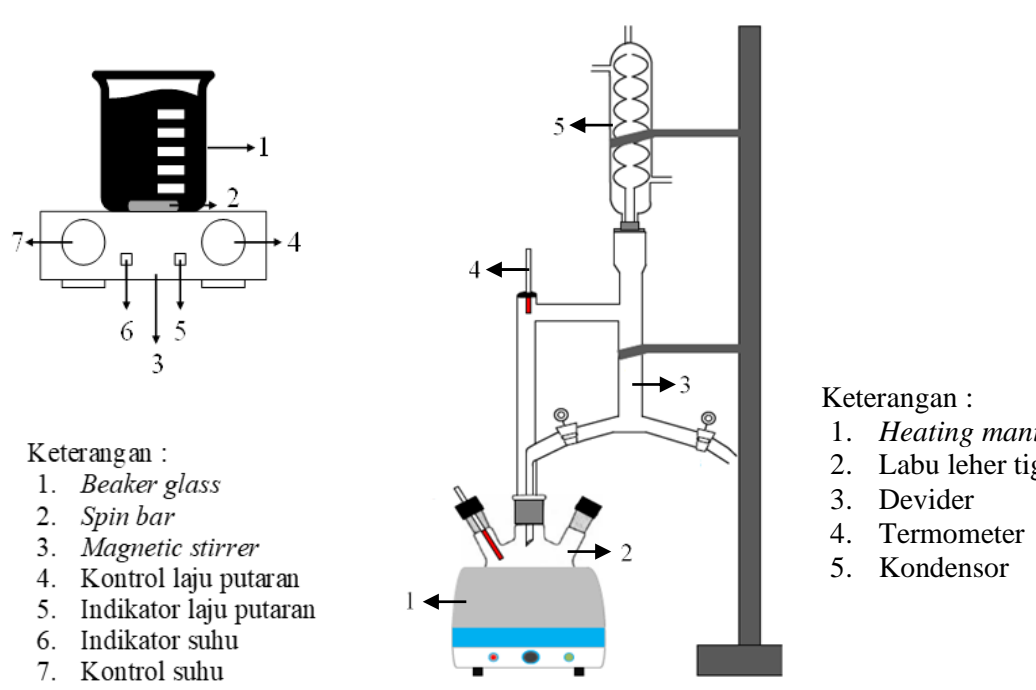

(a)

(b)

Gambar 1. Rangkaian Alat Ekstraksi Padat-Cair (a) dan Distilasi Uap-Air (b)

\subsection{Prosedur}

\section{1) Proses Ekstraksi Padat Cair}

Proses ektraksi padat cair ini dilakukan dengan memasukkan 100, 150, 200, 250, 300 gram jahe halus ke dalam labu ekstraktor. Siapkan $1000 \mathrm{ml}$ pelarut etanol, campuran n-heksana-etanol (1:1), dan n-heksana, lalu tambahkan pelarut dengan ke dalam labu ekstraktor. Ekstrasi dijalankan dengan kecepatan pengadukan $450 \mathrm{rpm}$ pada suhu $50^{\circ} \mathrm{C}$. selama 6 jam. Saring dan pisahkan ampas jahe dengan ekstrak untuk kemudian dilakukan proses pemisahan antara oleoresin dengan pelarut.

\section{2) Proses Pemurnian}

Proses distilasi ditujukan untuk memisahkan oleoresin jahe dengan pelarutnya. Filtrat dari proses ekstraksi dimasukan ke dalam labu leher tiga. Kemudian menyalakan heating mantle untuk memulai proses distilasi agar oleoresin jahe terpisah dengan pelarutnya. Proses distilasi dilakukan pada suhu titik didih pelarut hingga semua pelarut teruapkan. Suhu operasi pada saat menggunakan pelarut etanol adalah $78^{\circ} \mathrm{C}$, pada pelarut n-heksana $69^{\circ} \mathrm{C}$, dan pelarut campuran (etanol dan nheksana) titik didihnya $78^{\circ} \mathrm{C}$. Filtrat yang tidak menguap merupakan oleoresin jahe. Setelah didapatkan oleoresin jahe, kemudian dianalisis untuk mengetahui karateristiknya.

\section{3) Analisis Mutu Oleoresin}

\section{a) Rendemen}

Proses pengambilan minyak jahe yang dilakukan menggunakan proses leaching dengan dua jenis pelarut, yakni etanol $96 \%$ dan n-heksana bertujuan untuk mengetahui efektivitas pelarut terhadap rendemen minyak atsiri yang dihasilkan [11]. Untuk menghitung nilai kadar oleoresin dapat dihitung dengan berat oleoresin per berat sampel, sehingga cara hitungnya berlandaskan berat kering, yakni:

$$
\text { Rendemen }=\frac{\text { Berat oleoresin }(g r)}{\text { Berat sampel }(g r)} \times 100 \%
$$

\section{b) Kelarutan Oleoresin dalam Alkohol}

Percobaan larutan dalam alkohol oleoresin jahe dilakukan dengan mengambil $1 \mathrm{ml}$ sampel oleoresin menggunakan pipet, lalu dimasukkan ke tabung reaksi. Pengambilan sampel dikerjakan 1 jam setelah proses distilasi berakhir. Kemudian ditambahkan alkohol $90 \%$ dan tabung dikocok perlahan. Penambahan alkohol dilakukan hingga larutan tidak keruh. Nilai kelarutan oleoresin dalam alkohol ditentukan dari total kebutuhan alkohol dalam pengujian kelarutan $1 \mathrm{ml}$ sampel oleoresin. 
c) Berat Jenis (Densitas)

Pengukuran berat jenis dilakukan dengan mengambil $10 \mathrm{ml}$ aquadest menggunakan pipet dan dimasukkan ke dalam piknometer kemudian ditimbang. Selanjutnya mengambil $10 \mathrm{ml}$ oleoresin menggunakan pipet dimasukkan dalam piknometer dan ditimbang. Sampel oleoresin diambil 1 jam setelah distilasi berakhir. Berat jenis dapat dihitung dengan persamaan sebagai berikut:

$$
\text { Berat jenis }=\frac{\text { Berat } 10 \mathrm{mlminyak} \text { dalam } T^{\circ} \mathrm{C}}{\text { Berat } 10 \mathrm{ml} \text { air dalam } T^{\circ} \mathrm{C}}
$$

\section{d) Komponen Oleoresin}

Analisa komponen oleoresin dilakukan menggunakan metode pengujian GC-MS (Gas Chromatography Mass Spectrometry).

e) Putaran Optik

Analisis nilai putaran optik diawali dengan menyalakan sumber cahaya dan menunggu sampai diperoleh kilauan yang penuh. Memastikan tabung polarimeter bebas dari gelembung udara, kemudian sampel dimasukkan dalam tabung pada suhu $20^{\circ} \mathrm{C}$. Pada alat terdapat Skala yang dapat membaca nilai putaran optik dekstro (+) atau levo (-) pada sampel oleoresin. Mengukur suhu sampel $20^{\circ} \mathrm{C} \pm 1{ }^{\circ} \mathrm{C}$ dengan termometer yang disisipkan pada lubang tengah polarimeter.

\section{f) Indeks Bias}

Pengukuran indeks bias dilakukan dengan mengalirkan air melalui refraktometer sampai suhu $20^{\circ} \mathrm{C}$. Suhu dalam refraktometer dipertahankan dengan toleransi $\pm 0,2^{\circ} \mathrm{C}$. Mengukur suhu sampel oleoresin hingga suhunya $20^{\circ} \mathrm{C}$, kemudian dimasukkan dalam alat dan dilakukan pembacaan pada saat suhu sudah stabil [13].

\section{Hasil dan Pembahasan}

\subsection{Kadar Oleoresin (Rendemen)}

Rendemen merupakan salah satu penentu kualitas minyak atsiri yang menunjukkan nilai kandungan oleoresin di dalam rimpang jahe dan dinyatakan dengan persen [11]. Hasil dari masingmasing perlakuan terhadap rendemen oleoresin dapat dilihat Gambar 2.

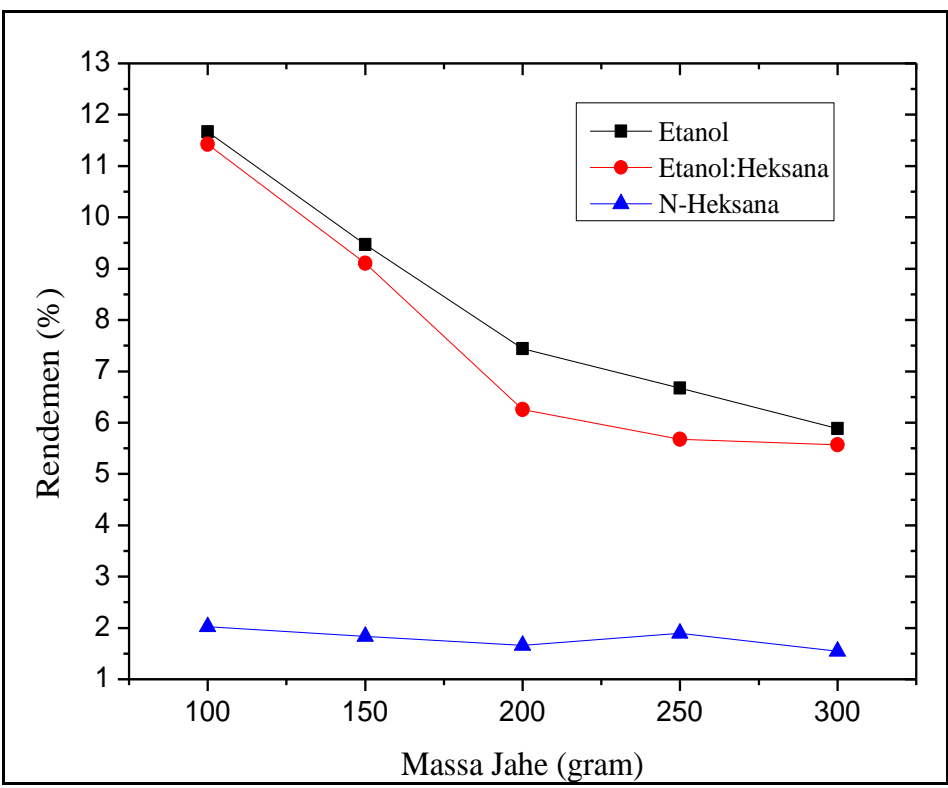

Gambar 2. Pengaruh Jenis Pelarut dan Massa Jahe Terhadap Rendemen Oleoresin Jahe

Berdasarkan data pada gambar, diketahui bahwa rendemen oleoresin tertinggi dihasilkan dari proses ekstraksi menggunakan pelarut etanol dengan massa jahe 100 gram. Sedangkan rendemen terendah dihasilkan dari proses ekstraksi menggunakan pelarut n-heksana. Akan tetapi pada kondisi 
campuran 1:1 nilai rendemen yang dihasilkan mendekati rendemen yang hasil ekstraksi dengan pelarut etanol. Hal ini dikarenakan jumlah oleoresin yang dihasilkan dipengaruhi oleh polaritas pelarut. Kelarutan suatu senyawa di dalam suatu pelarut tergantung pada sifat polaritas antara senyawa dan pelarut yang digunakan. Bahan-bahan dan senyawa kimia yang nilai polaritasnya sama dengan polaritas pelarut akan bersifat mudah larut ketika dilarutkan [9]. Jahe merupakan bahan yang bersifat polar karena senyawa-senyawa yang terkandung dalam jahe sebagian besar terdispersi oleh air. Oleh sebab itu, oleoresin lebih mudah terekstrak dengan pelarut etanol karena keduanya memiliki beda polaritas yang lebih kecil. Hal ini juga dikarenakan pelarut etanol adalah pelarut yang selektif terhadap minyak atsiri dibandingkan zat lain yang terkandung dalam senyawa campuran pada proses ekstraksi minyak atsiri jahe [3].

Massa bahan yang digunakan dalam proses ekstraksi dengan jumlah volume pelarut tetap akan mempengaruhi kadar oleoresin yang diperoleh. Semakin banyak massa bahan yang digunakan, maka luas tumbukan/permukaan kontak antar partikel minyak atsiri dengan partikel pelarut akan semakin kecil, begitu pula sebaliknya. Keluarnya minyak atsiri dari kelenjar minyak disebabkan adanya driving force akibat terjadinya tumbukan atau kontak diantara partikel dengan pelarut. Apabila kontak atau tumbukan antar partikel semakin kecil, minyak atsiri yang dihasilkan juga akan semakin kecil [14].

\subsection{Kelarutan dalam Alkohol}

Kelarutan oleoresin dalam alkohol ditentukan dari total kebutuhan alkohol dalam proses pelarutan $1 \mathrm{ml}$ sampel oleoresin. Kelarutan sampel dalam alkohol yang semakin besar, maka semakin baik mutunya. Kelarutan dalam alkohol dapat dilihat dari terlarutnya secara sempurna, tidak terbentuk gumpalan dan seiring bertambahnya alkohol, larutan akan semakin jernih [15]. Hasil dari pengujian kelarutan dalam alkohol dapat dilihat pada Tabel 2.

Tabel 2. Data Kelarutan Oleoresin dalam Alkohol (ml)

\begin{tabular}{cccc}
\hline \multirow{2}{*}{ Massa Jahe (gram) } & \multicolumn{3}{c}{ Pelarut (1000 ml) } \\
\cline { 2 - 4 } & Etanol & Etanol $: \boldsymbol{N}$-Heksana $(\mathbf{1}: \mathbf{1})$ & $\boldsymbol{N}$-Heksana \\
\cline { 2 - 4 } & \multicolumn{3}{c}{ Kebutuhan Alkohol (mL) } \\
\hline 100 & 0,5 & 2,2 & 12,8 \\
150 & 0,8 & 3,6 & 13,7 \\
200 & 1 & 4,8 & 13,8 \\
250 & 1,2 & 7 & 13,9 \\
300 & 2,8 & 7,2 & 17,6 \\
\hline
\end{tabular}

Penggunaan pelarut etanol menghasilkan oleoresin yang memiliki kelarutan dalam alkohol lebih besar dibandingkan dengan penggunaan pelarut $n$-heksana maupun campuran etanol-heksana. Komponen penyusun oleoresin merupakan faktor penting yang dapat menyebabkan adanya perbedaan nilai kelarutan oleoresin dalam alkohol. Komponen kimia yang mengandung gugus hidroksil akan mempengaruhi nilai kelarutannya. Kelarutan yang semakin tinggi disebabkan karena semakin banyak senyawa yang mengandung gugus hidroksil yang terkandung dalam oleoresin [11].

Minyak atsiri merupakan komponen yang tidak larut di dalam air, namun akan larut dalam alkohol. Alkohol sering digunakan sebagai bahan pemalsu karena harganya relatif murah dan dapat melarutkan semua jenis minyak atsiri. Minyak atsiri yang palsu biasanya memiliki kelarutannya rendah dalam alkohol. Oleh karena itu, pelarutan oleoresin dalam alkohol dapat ditujukan untuk menguji kemurnian minyak atsiri dalam oleoresin [15].

\subsection{Berat Jenis (Densitas)}

Salah satu cara yang digunakan dalam penentuan kualitas minyak dapat dilakukan dengan menentukan berat jenis atau densitas dari oleoresin jahe. Berat jenis oleoresin dinyatakan sebagai perbandingan antara berat oleoresin dengan berat air dalam volume dan suhu yang sama [11]. Pengaruh jenis pelarut terhadap berat jenis oleoresin yang dihasilkan dapat dilihat pada Gambar 3 . 


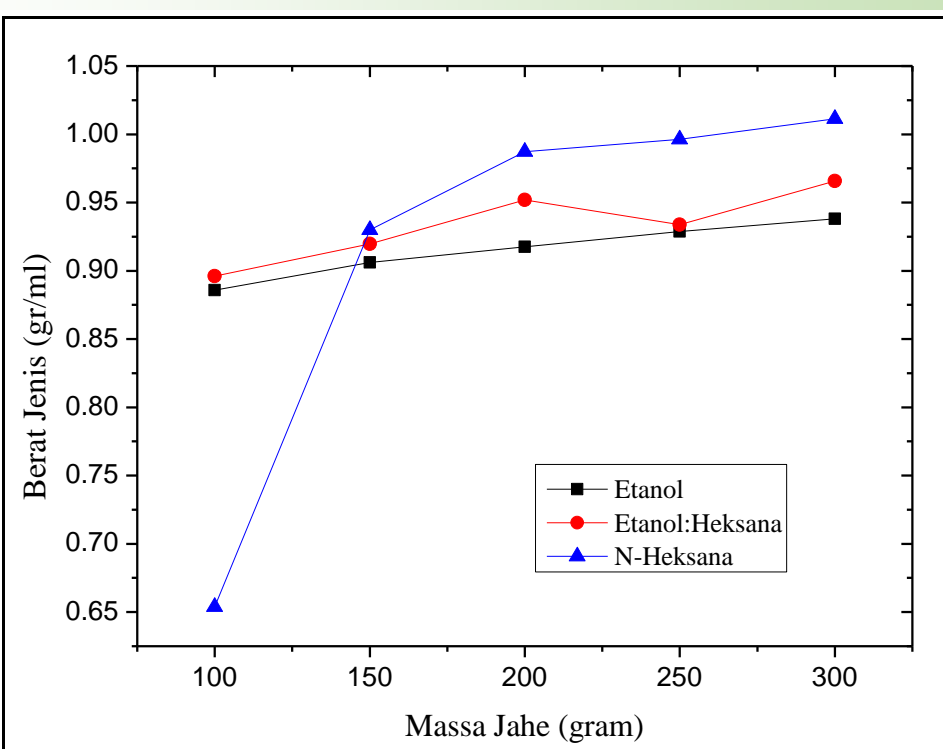

Gambar 3. Pengaruh Jenis Pelarut dan Massa Jahe Terhadap Berat Jenis Oleoresin Jahe

Dari data pada gambar, diketahui bahwa nilai berat jenis oleoresin jahe menggunakan pelarut Etanol berkisar antara 0,8858 - 0,9382 gr/mL. Berat jenis oleoresin jahe menggunakan campuran pelarut Etanol dan N-Heksana (1:1) berkisar antara 0,8960 - 0,9657 gr/mL. Sedangkan berat jenis untuk oleoresin jahe menggunakan pelarut $\mathrm{N}$-heksana berkisar antara $0,6538-1,0113 \mathrm{gr} / \mathrm{mL}$.

Perbedaan nilai berat jenis dapat disebabkan oleh beberapa faktor, yaitu jumlah dan jenis komponen yang terkandung dalam minyak atsiri [16]. Selain itu, jumlah ikatan rangkap dalam minyak yang semakin banyak akan menyebabkan terjadinya penurunan nilai densitas. Penurunan nilai densitas karena banyaknya ikatan rangkap dapat disebabkan oleh pemanasan pada suhu yang tinggi [17].

\subsection{Komponen Oleoresin}

Analisis komponen kimia dalam minyak atsiri adalah bagian penting untuk menentukan nilai mutu atau kualitas minyak atsiri yang dihasilkan. Berdasarkan hasil pengujian rendemen dan sifat fisik oleoresin yang terdiri dari pengujian kelarutan dalam alkohol serta berat jenis, mengacu pada standar mutu minyak jahe mengacu pada SNI 06-1312-1998. Analisa komponen kimia oleoresin dilakukan pada oleoresin jahe hasil ekstraksi menggunakan etanol dan 100 gram jahe yang memiliki nilai rendemen tertinggi dan mutu terbaik berdasarkan kelarutan dalam alkohol serta nilai densitas yang sesuai ketetapan Hasil analisa komponen kimia menggunakan GC-MS pada sampel oleoresin dapat dilihat pada Gambar 4.

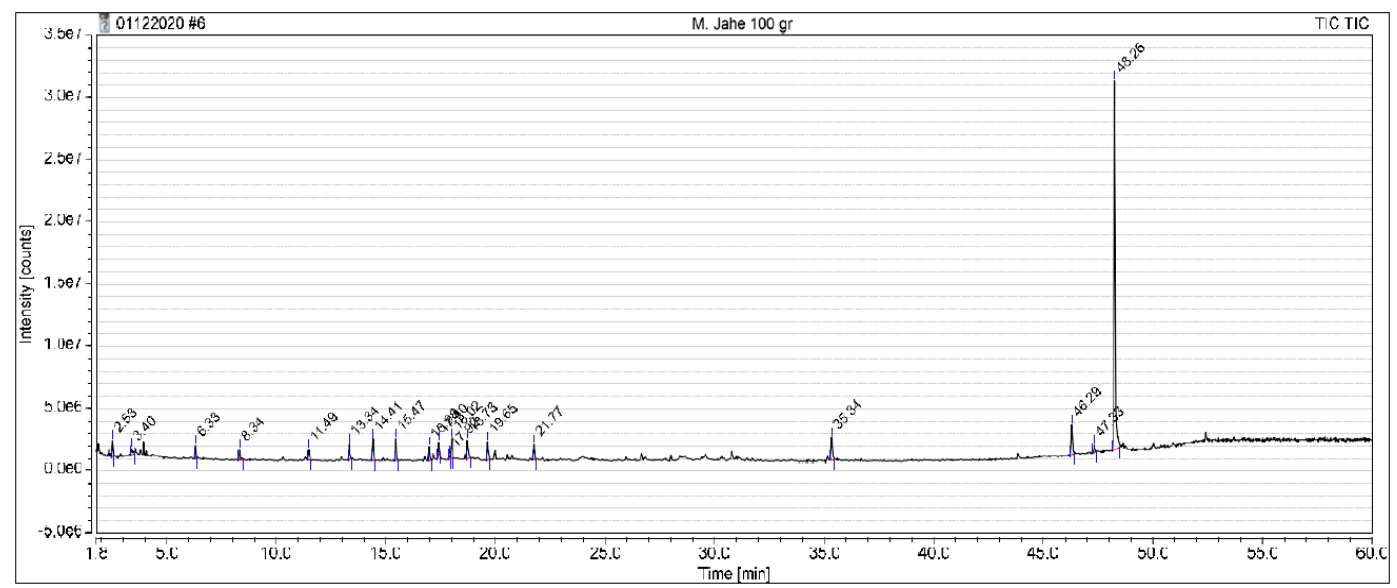

Gambar 4. Kromatogram Komponen Senyawa Kimia Oleoresin 100 gram Jahe Gajah Menggunakan Pelarut Etanol 
Berdasarkan puncak area kromatogram pada gambar, kandungan senyawa gingerol yang memiliki waktu retensi 48,26 menit dan persen luas area 58,97\%. Kromatogram oleoresin 100 gram jahe gajah yang diekstraksi dengan pelarut etanol menunjukkan adanya 19 puncak dengan kadar senyawa tertinggi gingerol. Beberapa komponen penyusun oleoresin dapat dilihat pada Tabel 3.

Tabel 3. Data Komponen Senyawa Kimia Oleoresin 100 gram Jahe Menggunakan Pelarut Etanol

\begin{tabular}{ccc}
\hline \multirow{2}{*}{ Massa Jahe (gram) } & \multicolumn{2}{c}{ Analisis Gas Chromatography Mass Spectrometry } \\
\cline { 2 - 3 } & Nama Senyawa & Kadar Senyawa (\%) \\
\hline & Gingerol & 58,97 \\
Shogaol & 4,65 \\
Drimenol & 3,56 \\
\multirow{2}{*}{100} & 3,16 \\
& Methyl 6-oxoheptanoate & 3,12 \\
& Endo-borneol & 2,94 \\
a-Terpineol & 2,90 \\
\hline
\end{tabular}

Untuk membandingkan hasil analisis komponen penyusun oleoresin 100 gram jahe, digunakan oleoresin hasil ekstraksi 300 gram jahe gajah yang memiliki nilai rendemen terendah pada penggunaan pelarut yang sama. Hasil analisis komponen dapat dilihat pada Gambar 5.

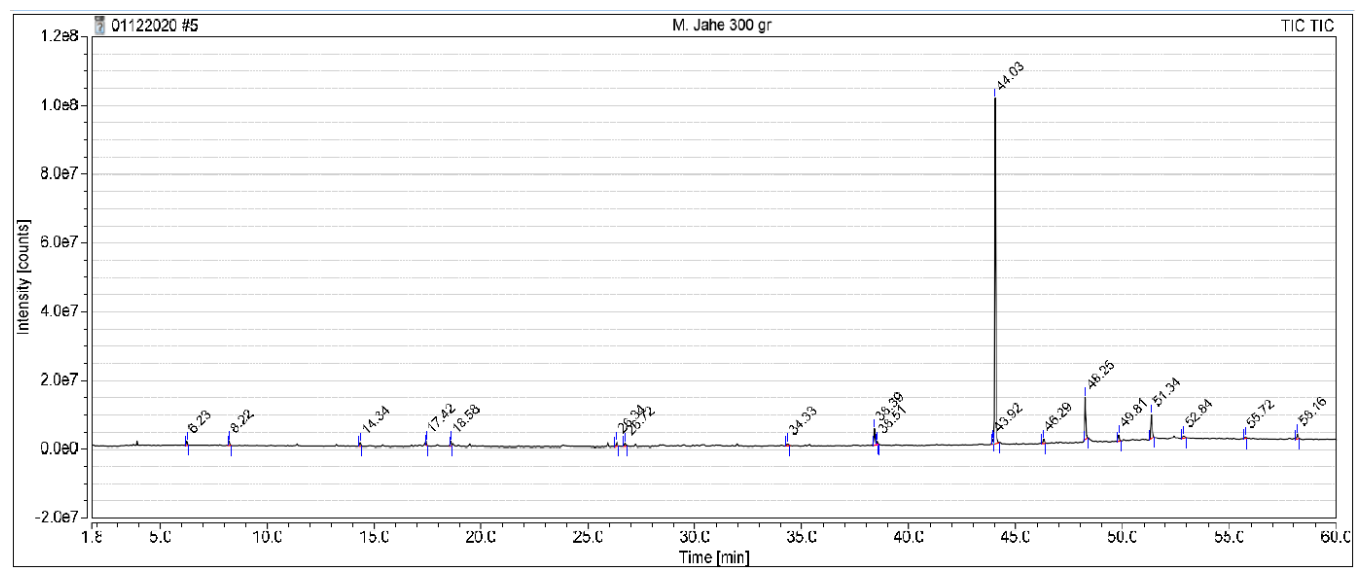

Gambar 5. Kromatogram Komponen Senyawa Kimia Oleoresin 100 gram Jahe Gajah Menggunakan Pelarut Etanol

Berdasarkan puncak area kromatogram pada gambar, kandungan senyawa eicosane memiliki waktu retensi 44,03 menit dengan persen luas area 66,30\%. Kromatogram oleoresin 300 gram jahe gajah yang diekstraksi dengan pelarut etanol menunjukkan adanya 19 puncak dengan kadar senyawa tertinggi eicosane. Beberapa komponen penyusun oleoresin dapat dilihat pada Tabel 4.

Tabel 4. Data Komponen Senyawa Kimia Oleoresin 300 gram Jahe Menggunakan Pelarut Etanol

\begin{tabular}{ccc}
\hline \multirow{2}{*}{ Massa Jahe (gram) } & \multicolumn{2}{c}{ Analisis Gas Chromatography Mass Spectrometry } \\
\cline { 2 - 3 } & Nama Senyawa & Kadar Senyawa (\%) \\
\hline Eicosane & 66,30 \\
Gingerol & 9,25 \\
300 & Phtalic acid, di(2-propylpentyl) ester & 7,06 \\
& Asam palmitat & 3,83 \\
Asam butoat & 1,64 \\
& Ethyl iso-allocholate & 1,46 \\
Hexasiloxane & 1,30 \\
\hline
\end{tabular}

Berdasarkan hasil uji GC-MS pada kedua sampel dapat diketahui bahwa gingerol muncul pada kedua minyak jahe yang diujikan. Gingerol merupakan salah satu senyawa khas yang terkandung dalam jahe segar. Senyawa khas tersebut adalah gingerol, shogaol dan zingeron. Aroma dan rasa yang khas dari jahe disebabkan oleh adanya ketiga senyawa tersebut [18]. 


\subsection{Putaran Optik dan Indeks Bias}

Jenis dan konsentrasi senyawa yang terkandung dalam oleoresin serta panjang jalan yang ditempuh sinar untuk melalui suatu senyawa mempengaruhi nilai putaran optiknya [11]. Nilai putaran optik dari minyak yang diperoleh merupakan campuran dari nilai putaran optik senyawasenyawa penyusunnya. Sedangkan nilai indeks bias merupakan parameter yang ditujukan untuk mengetahui komposisi dan konsentrasi larutan. Selain itu, indeks bias juga digunakan sebagai parameter kemurnian dan waktu kadaluarsa dari bahan [19]. Hasil analisis nilai putaran optik dan indeks bias dapat dilihat pada Tabel 5 .

Tabel 5. Data Nilai Putaran Optik Oleoresin Jahe Menggunakan Pelarut Etanol

\begin{tabular}{ccc}
\hline \multirow{2}{*}{$\begin{array}{c}\text { Massa Jahe } \\
\text { (gram) }\end{array}$} & \multicolumn{2}{c}{ Analisis Karakteristik } \\
\cline { 2 - 3 } & Putaran Optik & Indeks Bias \\
\hline 100 & $(+) 0,1716^{\circ}$ & $1,4964 \mathrm{nD}$ \\
200 & $(+) 0,2801^{\circ}$ & $1,4854 \mathrm{nD}$ \\
300 & $(+) 0,1402^{\circ}$ & $1,4642 \mathrm{nD}$ \\
\hline
\end{tabular}

Terdapat banyak senyawa kimia yang terkandung dalam oleoresin jahe, diantaranya zingiberene, camphene, curcumene, fellandren, citral, cineol dan zingiberol. Sifat putaran optik negatif dimiliki oleh senyawa zingiberene, sementara camphene dan curcume memilik sifat putaran optik positif [20].

Berdasarkan data pada Tabel 5, oleoresin yang dihasilkan memiliki nilai putaran optik positif. Hal ini tidak sesuai dengan nilai putaran optik yang ditetapkan SNI 06-1312-1998. Hal tersebut dapat disebabkan karena tidak adanya kandungan senyawa zingiberene pada oleoresin. Minyak jahe yang terdapat di Indonesia memiliki nilai putaran optik positif. Hal ini menjadi permasalahan utama para industri minyak jahe Indonesia, karena ketidak sesuaiannya dengan standar mutu internasional yang menyatakan bahwa nilai putaran optik bernilai negatif [21]. Nilai putaran optik yang positif disebabkan karena kecilnya kandungan zingiberene dalam minyak jahe yang dihasilkan dari proses destilasi dibandingkan komponen lain yang bersifat putaran optik positif. Kecilnya kadar zingiberene disebabkan oleh proses pemanasan suhu tinggi pada proses distilasi konvensional. Senyawa zingiberene memiliki sifat thermolabile, sehingga senyawa tersebut dapat terurai pada suhu tinggi.

Selain itu, dapat diketahui bahwa seiring bertambahnya massa jahe, nilai indeks biasnya semakin menurun. Kekuatan dan kerapatan minyak merupakan faktor yang dapat mempengaruhi nilai indeks bias. Kerapatan minyak yang semakin tinggi mengakibatkan nilai indeks bias semakin tinggi [22]. Semakin sedikit pelarut yang teruapkan, maka artinya sisa pelarut yang terkandung dalam oleoresin semakin tinggi dan menyebabkan nilai indeks bias oleoresin lebih rendah [23].

\section{Kesimpulan}

Jenis pelarut memiliki pengaruh penting terhadap karakteristik mutu dan rendemen oleoresin yang dihasilkan. Pelarut etanol merupakan pelarut terbaik dalam menghasilkan oleoresin yang memenuhi standar mutu karakteristik yang ditetapkan oleh SNI, yaitu nilai berat jenis $0,8876 \mathrm{gr} / \mathrm{ml}$ dan nilai indeks bias 1,4964. Penambahan massa jahe tidak berpengaruh terhadap rendemen yang dihasilkan. Rendemen tertinggi didapatkan pada penggunaan 100 gram jahe, yaitu 11,6630\%. Senyawa khas oleoresin jahe yakni gingerol dan shogaol teridentifikasi pada hasil uji GC-MS.

\section{Ucapan Terimakasih}

Ucapan terimakasih kami ucapkan serta penghargaan kami berikan kepada Universitas Pembangunan Nasional "Veteran" Jawa Timur, khususnya kepada Program Studi Kimia, Fakultas Teknik sebagai pihak yang membimbing dan memfasilitasi penelitian ini.

\section{Daftar Pustaka}

[1] BPS, "Produksi Tanaman Biofarmaka," 4 november, 2020. https://www.bps.go.id/site/resultTab (accessed Feb. 20, 2021). 
[2] K. Priyono, F. Rudi, and S. Rachmawati, "Pengambilan Minyak Atsiri dari Rimpang Jahe Merah menggunakan Metode Distilasi Uap dan Ekstrasi Air dengan Pemanas Microwave," Pros. Semin. Nas. Tek. Kim. “Kejuangan” Pengemb. Teknol. Kim. untuk Pengolah. Sumber Daya Alam Indones., no. April, pp. 1-7, 2018.

[3] R. D. Oktora, A. Aylianawati, and Y. Sudaryanto, "Ekstraksi Oleoresin dari Jahe," Widya Tek., vol. 6, no. 2, pp. 131-141, 2007.

[4] Koensoemardiyah, A to Z Minyak Atsiri Untuk Industri Makanan, Kosmetik dan Aromaterapi. 2010.

[5] W. L. McCabe, J. C. Smith, and P. Harriot, "Unit Operations Of Chemical Engineering, 5th Ed, McCabe And Smith.pdf.” p. 1154, 1993.

[6] K. B. A. Walangare, A. S. M. Lumenta, J. O. Wuwung, and B. A. Sugiarso, "Rancang Bangun Alat Konversi Air Laut Menjadi Air Minum Dengan Proses Destilasi Sederhana Menggunakan Pemanas Elektrik," e-Jurnal Tek. Elektrodan Komput., 2013.

[7] I. Rodianawati, P. Hastuti, and M. N. Cahyanto, "Nutmeg's (Myristica Fragrans Houtt) Oleoresin: Effect of Heating to Chemical Compositions and Antifungal Properties," Procedia Food Sci., vol. 3, pp. 244254, 2015, doi: 10.1016/j.profoo.2015.01.027.

[8] E. A. Saati, R. Asiyah, and M. Ariesandy, Pigmen Antosianin: Identifikasi dan Manfaatnya Bagi Industri Makanan dan Farmasi. 2016.

[9] M. K. Evania, "Studi literatur berbagai metode ekstraksi oleoresin pada biji pala, lada, dan jahe," Universitas Katholik Soegijapranata, 2015.

[10]B. S. Nasional, “SNI Minyak Jahe.” Desperindag, Badan Standarisasi Nasional, Jakarta, pp. 1-19, 1998.

[11]K. Kawiji, C. Anam, G. J. Manuhara, and M. I. Fakhrudin, “KAJIAN KARAKTERISTIK OLEORESIN JAHE BERDASARKAN UKURAN DAN LAMA PERENDAMAN SERBUK JAHE DALAM ETANOL," Caraka Tani J. Sustain. Agric., vol. 24, no. 1, p. 61, Mar. 2009, doi: 10.20961/carakatani.v24i1.14020.

[12]L. N. A. Lutfi, "Kandungan Asam Lemak Tak Jenuh Omega 3 Pada Tempe dengan Penambahan Tepung Ikan Lemuru," Universitas Jember, 2013.

[13]R. Anggraini, A. Jayuska, and A. H. Alimuddin, "Isolasi dan karakterisasi minyak atsiri lada hitam (piper nigrum 1.) asal sajingan kalimantan barat," J. Kim. Khatulistiwa, vol. 7, no. 4, pp. 124-133, 2018.

[14] S. Prasetyo and A. S. Cantawinata, "Pengaruh temperatur, rasio bubuk jahe kering dengan etanol, dan ukuran bubuk jahe kering terhadap ekstraksi oleoresin jahe (Zingiber officinale , Roscoe)," Semin. Rekayasa Kim. dan Proses, vol. 23, pp. C231-C237, 2010, [Online]. Available: http://eprints.undip.ac.id/28040/.

[15]D. T. Sihite, "Penentuan Rendemen Dan Mutu Minyak Pala (Myristic Fragran) Dari Daging Buah Dan Biji Pala," Skripsi Mhs. Teknol. Has. Hutan Fak. Pertan. Univ. Sumatera Utara, 2009.

[16]K. S. Nugraheni, L. U. Khasanah, R. Utami, and B. K. Ananditho, "Pengaruh Perlakuan Pendahuluan Dan Variasi Metode Destilasi Terhadap Karakteristik Mutu Minyak Atsiri Daun Kayu Manis (C. Burmanii)," J. Teknol. Has. Pertan., vol. IX, no. 2, pp. 51-64, 2016, [Online]. Available: javascript: $\operatorname{void}(0)$.

[17] S. M. Sutan, Y. Hendrawan, and D. A. Tipdani, "Kajian Pemanasan Pada Proses Ekstraksi Minyak Jarak (( Jatropha Curcas L .) Menggunakan Hydraulic Press,” vol. 6, no. 1, pp. 63-71, 2018.

[18]A. Setyawan, "Keragaman Varietas Jahe (Zingiber officinale Rosc.) berdasarkan Kandungan Kimia Minyak Atsiri," BioSMART J. Biol. Sci., vol. 4, no. 2, pp. 48-54, 2002, [Online]. Available: http://biosmart.mipa.uns.ac.id/index.php/biosmart/article/view/104.

[19] W. Mahmood Mat Yunus, Y. W. Fen, and L. M. Yee, "Refractive index and fourier transform infrared spectra of virgin coconut oil and virgin olive oil," Am. J. Appl. Sci., vol. 6, no. 2, pp. 328-331, 2009, doi: 10.3844/ajas.2009.328.331.

[20]H. Purwanto, I. Hartati, and L. Kurniasari, "Pengembangan Microwave Assisted Extractor (Mae) Pada Produksi Minyak Jahe Dengan Kadar Zingiberene Tinggi," J. Momentum UNWAHAS, vol. 6, no. 2, pp. 9-16, 2010. 
[21]L. Kurniasari, I. Hartati, and R. Ratnani, "Kajian Ekstraksi Minyak Jahe Menggunakan Microwave Assisted Extraction (Mae)," J. Momentum UNWAHAS, vol. 4, no. 2, p. 114974, 2008.

[22]H. Nisak and N. L. Rahmah, "Teknologi Kejut Listrik Terhadap Mutu Minyak Atsiri Concrete ( Kajian Rasio Bahan Baku, Pelarut Heksana , Dan Lama Kejutan Listrik ) White Jasmine Extraction Using Electric Pulse To Concrete Essential Oil Quality ( Study on Raw Material Ratio , Hexane So," J. Ind., vol. 3, 2015.

[23]N. Arpi, S. Satriana, and K. Rezekiah, "Ekstraksi Oleoresin dari Limbah Penyulingan Pala Menggunakan Ultrasonik," J. Rekayasa Kim. Lingkung., vol. 9, no. 4, p. 180, 2013, doi: 10.23955/rkl.v9i4.1232. 